\title{
Bifunctional Phenol Quinone Methide Precursors: Synthesis and Biological Activity
}

\author{
Matija Sambol, ${ }^{1,2}$ Katja Ester, ${ }^{3, *}$ Antonija Husak, ${ }^{1}$ Đani Škalamera, ${ }^{1,4}$ Ivo Piantanida, ${ }^{1}$ Marijeta Kralj, ${ }^{3}$ Nikola Basarić ${ }^{1, \#}$
}

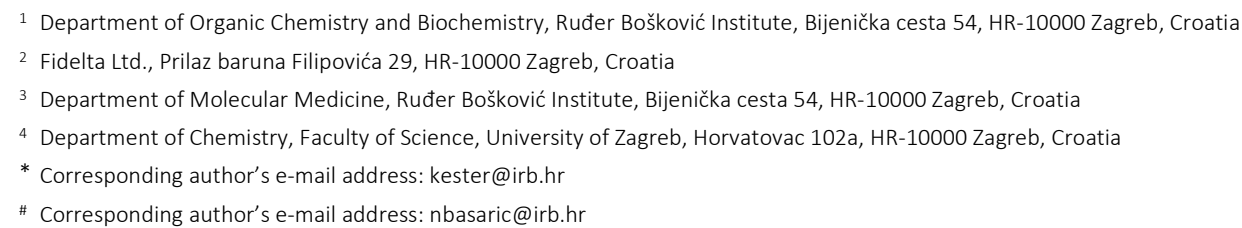

RECEIVED: November 27, 2018 * REVISED: January 28, 2019 * ACCEPTED: January 28, 2019

Abstract: New bifunctional quinone methide ( $Q M)$ precursors, bisphenols 2a-2e, and monofunctional QM precursor 7 were synthesized. Upon treatment with fluoride, desilylation triggers formation of reactive intermediates, QMs, which was demonstrated by trapping QM with azide or methanol. The ability of QMs to alkylate and cross-link DNA was assayed by investigation of the effects of QMs to DNA denaturing, but without conclusive evidence. Furthermore, treatment of a plasmid DNA with compounds $2 \mathrm{a}-2 \mathrm{e}$ and $\mathrm{KF}$, followed by the analysis by alkaline denaturing gel electrophoresis, did not provide evidence for the DNA cross-linking. MTT test performed on two human cancer cell lines (MCF7 breast adenocarcinoma and SUM159 pleomorphic breast carcinoma), with and without fluoride, indicated that 2a-2e or the corresponding QMs did not exhibit cytotoxic activity, in line with the lack of ability to cross-link DNA. The lack of reactivity with DNA and biological activity were explained by sequential formation of QMs where bifunctional cytotoxic reagent is probably never produced. Instead, the sequential generation of monofunctional QM followed by a faster hydrolysis leads to the destruction of biologically active reagent. The findings described here are particularly important for the rational design of new generation of QM precursor molecules that will attain desirable DNA reactivity and cytotoxicity.

Keywords: antiproliferative activity, DNA alkylation, Grignard reaction, nucleic acid, quinone methide, structure-based drug design.

\section{INTRODUCTION}

Q UINONE methides (QMs) are important intermediates in chemistry and photochemistry of phenols, ${ }^{[1]}$ owing to their applications in organic synthesis, ${ }^{[2]}$ and biological activity. ${ }^{[3]}$ It has been demonstrated that $Q M s$ react with amino acids ${ }^{[4]}$ and proteins, ${ }^{[5]}$ and inhibition of some enzymes has been reported including hydroxylases, ${ }^{[6]} \beta$-lactamase, ${ }^{[7]} \beta$-glucosidases, ${ }^{[8]}$ phosphatase $^{[9]}$ or ribonuclease-A. ${ }^{[10]}$ However, biological action of QMs has mostly been related to their reactivity with nucleosides ${ }^{[11]}$ and alkylation of DNA, ${ }^{[12]}$ since some anticancer antibiotics such as mitomycin ${ }^{[13]}$ exert their antiproliferative action on metabolic formation of QMs that alkylate DNA. In particular, S. Rokita et al. demonstrated reversible alkylation ability of QMs leading to "immortalization of QM" by DNA as a nucleophile, ${ }^{[14]}$ whereas Freccero et al. investigated ability of QMs to alkylate $\mathrm{G} 4$ regions of DNA. ${ }^{[15]}$

QMs are very reactive species that cannot be stored, they have to be generated in situ. Some thermal reactions to generate QMs include oxidation of phenols, ${ }^{[16]}$ dehydration from hydroxybenzyl alcohols, ${ }^{[17]}$ elimination of nitriles from 1,2-benzoxazines, ${ }^{[18]}$ and the most extensively used, fluoride induced desilylation. ${ }^{[12 b, c]}$ On the other hand, photochemical methods offer much milder approach to QMs, particularly for biological systems. ${ }^{[19]}$ The most common reactions to generate $\mathrm{QMs}$ in photochemical reactions are photodehydration ${ }^{[20]}$ and photodeamination from the suitably substituted phenols. ${ }^{[4,21]}$ An on-going interest in our group is the photochemical generation of quinone methides (QM) from suitable precursors, and investigation of their biological effects. ${ }^{[22]}$ In particular, we have recently demonstrated that photogenerated $\mathrm{QM}$ 
<smiles>OCc1cc2cc3ccccc3cc2cc1O</smiles>

1<smiles>COc1ccccc1</smiles><smiles>C=C1C=c2cc3ccccc3cc2=CC1=O</smiles>

QM1<smiles>N#Cc1cc2cc3ccccc3cc2cc1O</smiles>

$1-\mathrm{Nu}$

Scheme 1. Photochemical dehydration on anthrol 1 and formation of QM1 that exhibits cytotoxicity on cancer stem cells.

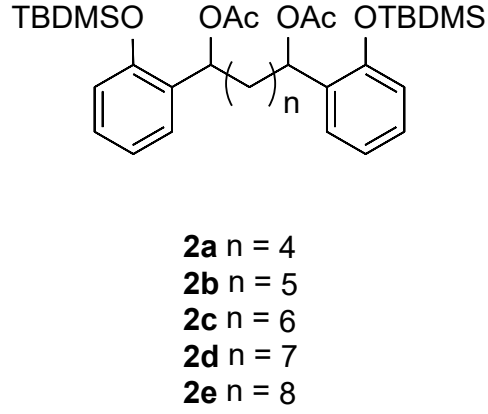

Figure 1. Structures of bifunctional QM precursors.

formed from anthrol 1 (Scheme 1) exhibit higher cytotoxicity on cancer stem cell lines then on normal cancer cells. ${ }^{[23]}$ Interestingly, our results indicate that enhanced antiproliferative effects probably does not originate from the reaction of QMs with DNA, but rather with proteins, since we have shown that compounds do not enter cell nucleus. ${ }^{[22 d, 23]}$ However, all molecules that we studied to date were monofunctional, so in principle, they could only alkylate DNA. On the other hand, DNA cross-linking by bifunctional molecules is known to be the most cytotoxic event leading to the cell death. ${ }^{[24]}$

Herein we report an investigation of $\mathrm{F}^{-}$induced desilylation and generation of bi-functional QMs that are anticipated to enable DNA cross-linking (Figure 1).
Bisphenol derivatives $\mathbf{2}$ are bi-functional derivatives of phenols that are substituted by TBDMS at the phenolic oxygen and by acetyl at the benzyl alcohol. According to literature precedent, $\mathrm{F}^{-}$induced desilylation should induce the cleavage of the silyl group, elimination of the acetyl and formation of QMs. ${ }^{[12 b, c]}$ The QM precursors are separated by alkyl spacer of different lengths to probe for the effect of molecular structure to the efficiency of DNA crosslinking.

Formation of $\mathrm{QMs}$ was probed by $\mathrm{F}^{-}$induced reactions and trapping with nucleophiles. Antiproliferative activity of bisphenols was investigated in vitro against two human cancer cell lines: MCF-7 (breast adenocarcinoma) and SUM159 (pleomorphic breast carcinoma). The idea was to link the antiproliferative activity to the ability of QMs to cross-link DNA molecules. Interestingly, treatment of plasmid DNA in the presence of bisphenols and analysis by alkaline agarose electrophoresis, or measurement of DNA denaturation show that QMs do not cross-link plasmid DNA, and the reasons for the lack of reactivity were disclosed.

\section{RESULTS}

\section{Synthesis}

Synthesis of bis-QM precursors was based on the one-pot double Grignard reaction with the appropriately protected

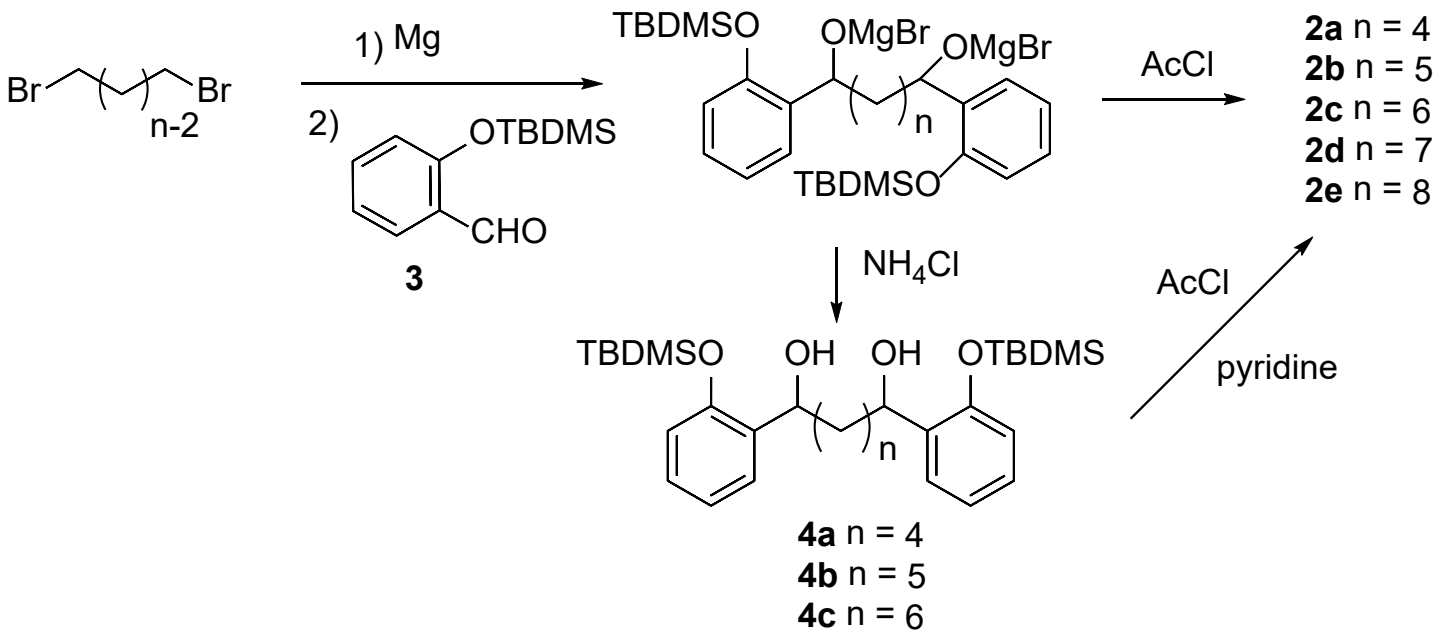

Scheme 2. Synthesis of bisphenol QM precursors. 


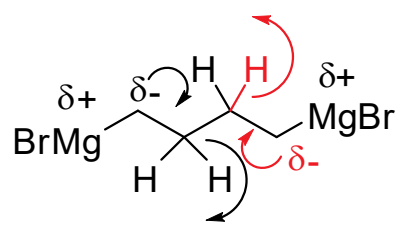

Figure 2. Structure of C-4 di-Grignard reagent that is prone to $\beta$-hydride transfer.<smiles>CS(=O)(=O)Oc1ccccc1CO</smiles>

5<smiles>CCCCOc1ccccc1C(O)CC</smiles>

6<smiles>CCCOc1ccccc1C(CC)OC(C)=O</smiles>

7
Figure 3. Structure of products 5-7.

carbaldehyde. Salicylaldehyde component was TBDMSprotected $\mathbf{3}^{[25]}$ (for the preparation see the $\mathrm{SI}$ ) that reacted with double Grignard reagent formed from 1,n-dibromoalkane. The reaction gave alkoxide intermediates that can be quenched by $\mathrm{H}_{2} \mathrm{O}$ and isolated as alcohols 4 , or acetylated in one-pot (Scheme 2). An attempt to quench the alkoxide with acetic anhydride failed, but the treatment with acetyl chloride was successful giving acetyl esters. The one pot procedure gave better yields and one purification step less was needed. It should be noted that the double Grignard reaction created two stereogenic centers in $\mathbf{4}$ or 2, and therefore, a mixture of two enantiomers $(R R, S S)$ and the meso-compound $(S R)$ were obtained, which were inseparable by achiral chromatography.

On attempts to prepare bisphenol containing alkyl spacer with less than $6 \mathrm{C}$-atoms, in the Grignard reaction with 1,4-dibromobutane or 1,3-dibromopropane, a reduction of the TBDMS-protected aldehyde took place giving benzyl alcohol 5. Such $\beta$-hydride transfer reactions are known to compete with Grignard reactions, ${ }^{[26]}$ particularly with sterically congested carbonyl groups. ${ }^{[27]}$ In our case, the di-Grignard reagent formed from 1,4-dibromobutane contained reactive $\mathrm{H}$-atoms at the $\beta$-position (Figure 2 ), allowing the facile $\beta$-hydride transfer and preventing the addition to the carbonyl group. Furthermore, based on literature precedent, formation of di-Grignard reagent from 1,3-dibromopropane is proble-matic since the di-
Grignard reagent is very unstable. ${ }^{[28]}$ Therefore, only bisphenols containing more than $6 \mathrm{C}$ atoms in the linker were synthesized. In addition to bisphenol derivatives, we have synthesized also model compounds $\mathbf{6}$ and $\mathbf{7}$ (Figure 3), that contain only one phenol moiety, and which were needed in the biological investigations.

\section{QM Formation by $\mathrm{F}^{-}$Induced Desilylation}

Formation of QM in the desilylation reaction was first probed on model compound 7. The compound was dissolved in DMSO and diluted with PBS buffer ( $\mathrm{pH}$ 7.4). Formation of QM was initiated by addition of KF (incubation $1 \mathrm{~h}$ ). The formation of QMs was proven by quenching with nucleophiles, $\mathrm{NaN}_{3}$, the ubiquitous $\mathrm{QM}$ quencher ${ }^{[19]}$ whereupon adduct 8 was isolated by preparative HPLC (Scheme 3). Furthermore, we have shown that adducts were formed practically immediately after the addition of $\mathrm{KF}$, whereas in the absence of KF adducts were not formed over $24 \mathrm{~h}$.

To show that bisphenols can also undergo $\mathrm{F}^{-}$ desilylation giving QMs we have treated $2 \mathrm{c}$ with $\mathrm{KF}$ in methanolic solution. The reaction gave two products 9 and 10 (Scheme 4) that were isolated and characterized. Formation of 10 , where only one benzyl alcohol is substituted by methoxy group indicates that formation of QMs and methanolysis probably take place sequentially. That is, upon formation of a $\mathrm{QM}$, the reaction of solvolysis probably takes place more rapidly than formation of the second QM in the same molecule. Thus, it is not probable that one molecule contains two QM centers at the same time.

\section{Investigation of DNA Cross-linking Ability of Compounds}

After demonstrating that $\mathrm{F}^{-}$induces formation of $\mathrm{QMs}$, DNA cross-linking ability of bisphenols 2 was assayed. Plasmid pCMVbeta DNA $(2 \mu \mathrm{g})$ in PBS buffer was mixed with 2a-2e and $\mathbf{7}(1 \mathrm{mM})$, and treated with KF (200 mM). After $18 \mathrm{~h}$ incubation, the alkaline agarose gel electrophoresis was performed, as described in the Experimental section. As a positive control, plasmid was irradiated in the presence of psoralene derivative that is known to cross-link DNA. ${ }^{[12 d]}$ Interstrand cross-linking activities of psoralen were evident as X-band of circular form (X-CC). However, no $X$-bands and no difference in migratory ability compared to control DNA were observed in the presence of $\mathbf{2}$ (Figure 4).

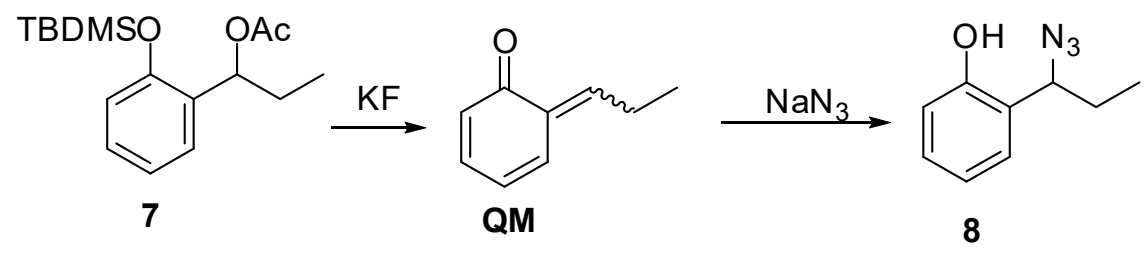

Scheme 3. $\mathrm{F}^{-}$induced formation of $\mathrm{QM}$ and reaction with $\mathrm{NaN}_{3}$. 
<smiles>CO[R16](C)(C)CCCCCC(OC(C)=O)c1ccccc1OS(C)(=O)=O</smiles>

2c<smiles>COC(CCCCCCC(OC)c1ccccc1O)c1ccccc1O</smiles><smiles>COC(CCCCCCC(OC(C)=O)c1ccccc1O)c1ccccc1O</smiles>

Scheme 4. $\mathrm{F}^{-}$induced methanolysis from bisphenol 2c.

\section{Investigation of the DNA Cross-linking by Thermal Denaturation}

Compounds that bind to DNA cause stabilization of the duplex and increase of the DNA melting temperature $\left(\Delta T_{\mathrm{m}}\right)$. Similarly, we anticipated that the covalent binding, and particularly, cross-linking of DNA should affect the $\Delta T_{\mathrm{m}}$. Therefore, the ability of compounds $\mathbf{2} \mathbf{b}-\mathbf{2} \mathbf{e}$ to form bifunctional QMs and cross-link DNA was assayed also by their effects on $\Delta T_{\mathrm{m}}$ (Figure 5 and Figures $\mathrm{S} 1$ and $\mathrm{S} 2$ in the supporting information). The problem in the measurement represented poor solubility of $\mathbf{2}$ under these conditions. Therefore, the measurement was conducted in $\mathrm{H}_{2} \mathrm{O}-\mathrm{DMSO}$ solvent mixture $(9: 1$, or $8: 2$ for $\mathbf{2 c})$, containing sodium cacodylate buffer $(c=0.05 \mathrm{M}, \mathrm{pH}=7.0)$. Under such conditions, ct-DNA revealed $T_{\mathrm{m}}=75.1 \pm 0.5{ }^{\circ} \mathrm{C}$. Addition of compounds alone or in combination with $\mathrm{KF}$ did not affect the $T_{\mathrm{m}}$ significantly, changes being within the error of the method $\left( \pm 0.5{ }^{\circ} \mathrm{C}\right.$, Figure 5$)$, suggesting that the eventual alkylation and cross-linking was either of very low efficiency (leaving large amount of free DNA available for denaturation) or did not take place at all. However, the thermal denaturation experiment could not give the unambiguous conclusion whether QMs from 2 were able to alkylate and cross-link at least some of DNA, since even low cross-linking efficiency could have measurable biological effect. Therefore, we decided to assay these systems on human cancer cell lines.

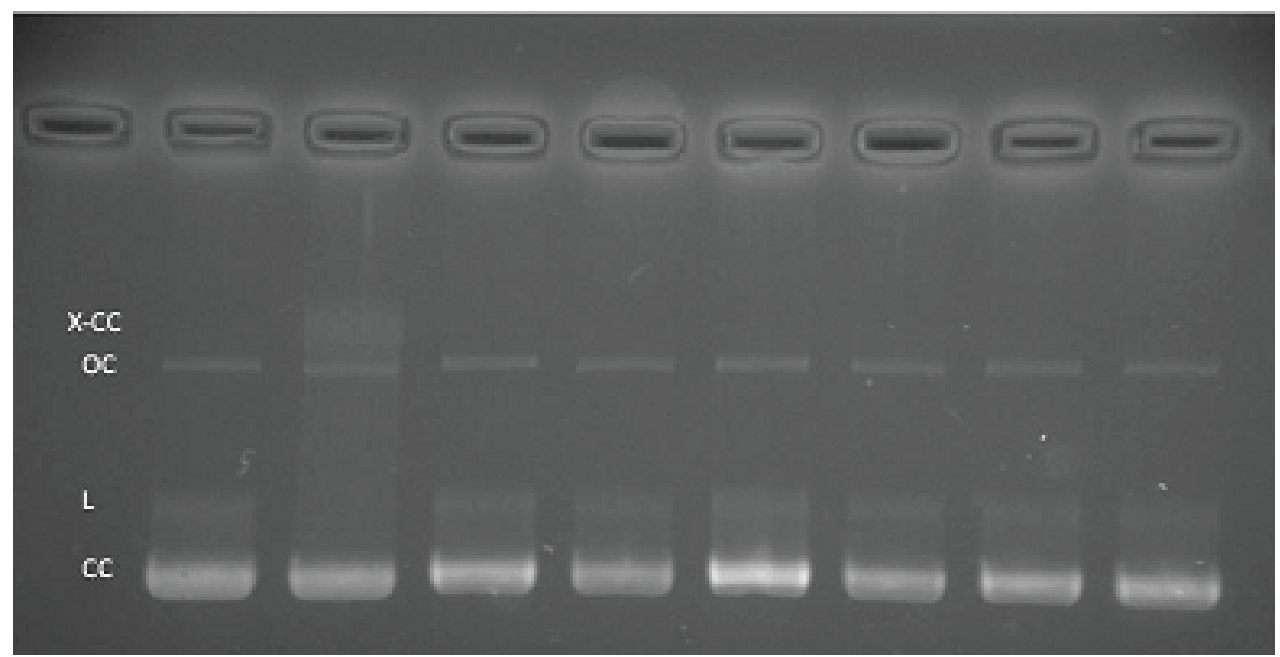

Figure 4. Alkaline agarose gel electrophoresis: pCMVbeta plasmid DNA $(2 \mu \mathrm{g})$ in PBS buffer $(\mathrm{pH}=7.4)$ was mixed with $2 \mathrm{a}-2 \mathrm{e}$ or $7(1 \mathrm{mM})$, and KF (200 mM). After $18 \mathrm{~h}$ incubation, the samples were loaded and the gel was running for $5 \mathrm{~h}$. Columns from left to right: 1) plasmid DNA, 2) psoralen (PS) $(20 \mu \mathrm{M})$ and irradiation 5 min at $300 \mathrm{~nm}, 3) 2 \mathrm{a} \mathrm{4)} \mathrm{2b,} \mathrm{5)} \mathrm{2c,} \mathrm{6)} \mathrm{2d,} \mathrm{7)} \mathrm{2e,} \mathrm{8)} \mathrm{7.} \mathrm{CC-closed}$ circular DNA, OC-open circular DNA, L-linear DNA, X-cross-linked DNA. 


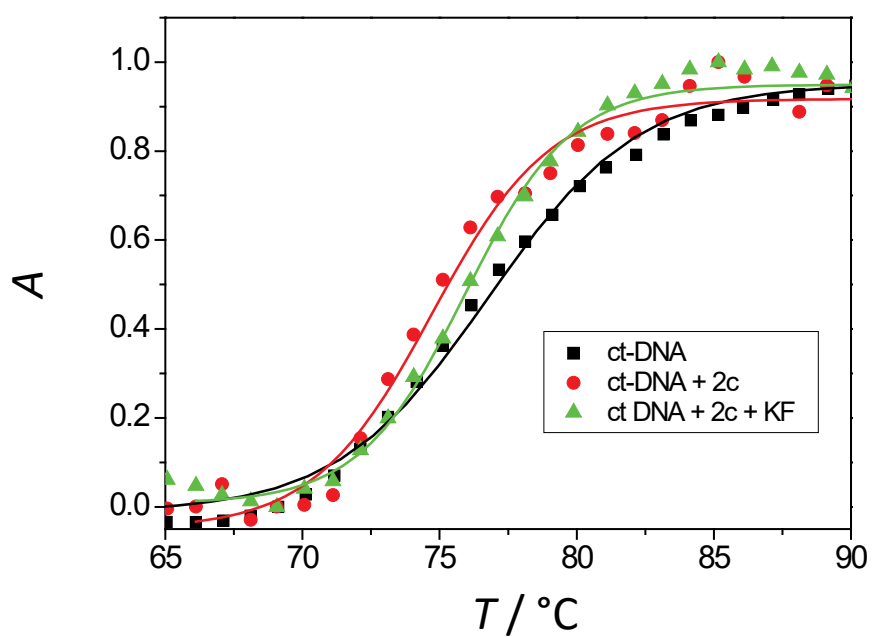

Figure 5. Normalized dependence of the ct-DNA $\left(1.76 \times 10^{-5} \mathrm{M}\right)$ absorbance at $260 \mathrm{~nm}$, in $\mathrm{H}_{2} \mathrm{O}-\mathrm{DMSO}(8: 2)$ containing sodium cacodylate buffer $(c=0.05 \mathrm{M}, \mathrm{pH}=7.0)$, neat or in the presence of $2 \mathrm{c}\left(1.6 \times 10^{-3} \mathrm{M}\right)$, or $2 \mathrm{c}\left(1.6 \times 10^{-3} \mathrm{M}\right)$ and $\mathrm{KF}(0.2 \mathrm{M})$ after incubation for $3 \mathrm{~h}$.

\section{Antiproliferative Activity}

Antiproliferative effect of the $\mathrm{F}^{-}$generated $\mathrm{QMs}$ on two cancer cell lines, MCF7 (breast adenocarcinoma) and SUM159 (pleomorphic breast carcinoma) was investigated. Cells were divided into two groups; cells treated with compounds and $\mathrm{KF}$, and cells that were treated only with compounds. KF was added two hours after the compounds in order to allow bisphenols to permeate the cell's membrane. Cells were incubated with all of the compounds for three days. The activities expressed as $\mathrm{IC}_{50}$ (concentration that causes $50 \%$ inhibition of the cell growth) are compiled in Table 1. In general, all of the compounds exhibited low antiproliferative activity. Compound $\mathbf{7}$ had moderate activity toward MCF7 cells. We observed enhancement of cytotoxicity in SUM159 cells upon activation of compound $\mathbf{7}$ with KF, but this effect could also be attributed to toxicity of KF toward SUM159 cell line
(Figure S4). Small improvement of cytotoxicity was also observed in MCF7 cells after activation of compound $\mathbf{2 d}$.

\section{DISCUSSION}

The treatment of monofunctional QM precursor 7 with KF in the presence of azide whereupon adduct $\mathbf{8}$ was isolated clearly indicated that $\mathrm{F}^{-}$induced formation of $\mathrm{QMs}$, in accord with literature precedent. ${ }^{[12 b, c]}$ Furthermore, KF induced methanolysis of bisphenol $\mathbf{2 c}$, indicating that formation of QMs takes place upon treatment of $2 a-2 e$ with $\mathrm{KF}$. However, we do not have any evidence if the formation of bis-QM takes place (such as 2a-bisQM, Scheme 5). Namely, it is plausible that $\mathrm{F}^{-}$induced formation of $\mathrm{QM}$ takes place stepwise giving 2a-QM. In principle, this monofunctional QM molecule can undergo two competitive reactions, hydrolysis to $\mathbf{1 1}$ and secondary elimination to

Table 1. IC $C_{50}$ values (in $\left.\mu \mathrm{M}\right)^{(\mathrm{a})}$ induced with compounds 2 and 7

\begin{tabular}{|c|c|c|c|c|}
\hline \multirow[b]{2}{*}{ Comp. } & \multicolumn{2}{|c|}{ SUM159 } & \multicolumn{2}{|c|}{ MCF7 } \\
\hline & $\mathrm{No} \mathrm{F}^{-}$ & $\mathrm{F}^{-}(1 \mathrm{mM})$ & No $F^{-}$ & $\mathrm{F}^{-}(1 \mathrm{mM})$ \\
\hline $2 a$ & $>100$ & $>100$ & $>100$ & $>100$ \\
\hline $2 b$ & $>100$ & $>100$ & $>100$ & $>100$ \\
\hline $2 c$ & $>100$ & $>100$ & $>100$ & $>100$ \\
\hline $2 d$ & $>100$ & $>100$ & $>100$ & $77 \pm 27$ \\
\hline $2 e$ & $>100$ & $>100$ & $>100$ & $>100$ \\
\hline 7 & $>100$ & $63.5 \pm 0.6$ & $28 \pm 4$ & $24 \pm 2$ \\
\hline
\end{tabular}

(a) Concentration that causes $50 \%$ inhibition of tumor cell growth. 
<smiles>CCCCCCC(OC(C)=O)c1ccccc1OCCCCC(OC(C)=O)c1ccccc1OCC</smiles>

2a

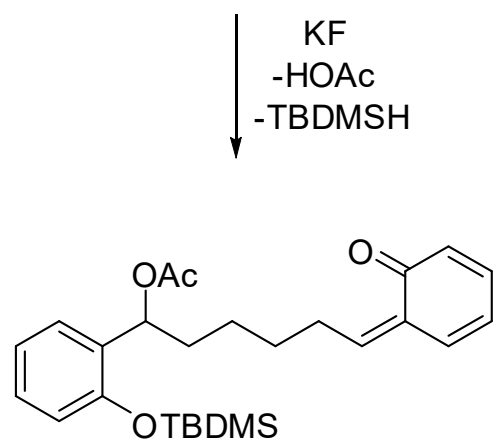

2a-QM<smiles>CCCCC(O)c1ccccc1OC(C)C(=O)O</smiles>

11

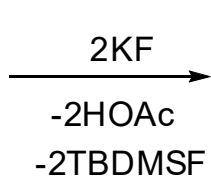

?<smiles>C[R16](C)(C)O</smiles>

\section{2a-bis QM}<smiles>O=C(O)CCCCCC(O)c1ccccc1O</smiles>

12<smiles>O=C1C=CC=CC1=CCCCCC(O)c1ccccc1O</smiles>

$11-Q M$

Scheme 5. Plausible pathways for the formation of QM and bisQM from 2a and their hydrolysis.

2a-bisQM. The concentration of 2a-bisQM is therefore determined by a ratio of the corresponding reaction rate constants and concentrations $\left[\mathrm{F}^{-}\right]$vs $\left[\mathrm{H}_{2} \mathrm{O}\right]$. Hydrolyzed product 11 can also undergo $\mathrm{F}^{-}$induced elimination giving 11QM. Eventually, both reactive sides in $\mathbf{2 a}$ are used and transformed to the bis-hydroxymethylphenol 12, which is not reactive.

Pathways presented in Scheme 5 may account for the lack of DNA cross-linking with compounds 2 . Namely, the cross-linking is only feasible if 2a-bisQM is formed, or if 2a-QM reacts faster with DNA then with $\mathrm{H}_{2} \mathrm{O}$. Although, the hydrolyzed product $\mathbf{1 1}$ forms $\mathbf{1 1 - Q M}$, it can only alkylate DNA and cannot induce DNA cross-linking. This situation is different to bifunctional phenols bearing leaving groups at the position 2 and 6 , such as 13 . We have demonstrated by transient spectroscopy that $\mathbf{1 3}$ undergoes photodeamination giving 13-QMa. The attack of a nucleophile to 13$\mathrm{QMa}$ at the methylene 2 position gives new QM with a methylene at the 6 position, 13-QMb (Figure 6).[21b] This specific reactivity of bifunctional QMs leads to long-lived transient species and enable reversible reactions of the QM along a DNA chain as if the QM "walks on the DNA".[29]

Attempts to induce DNA cross-linking by $\mathbf{2 a - 2 e}$ and $\mathbf{7}$, and probe the process by the alkaline agarose gel electrophoresis or thermal denaturation failed, or gave no unambiguous conclusion. Furthermore, we have shown that compounds in the presence of KF do not exhibit cytotoxicity. These findings indicate that bisphenols 2 probably do not form bifunctional QMs. Consequently, they cannot cross-link DNA and do not show significant cytotoxicity.

\section{CONCLUSION}

Monofunctional and bifunctional quinone methide (QM) precursors were synthesized and their ability to form QMs in the reaction with fluoride was demonstrated. The ability 
<smiles></smiles>

13<smiles>C=C1C=C(C)C=C(C[NH2+]C(C)C)C1=O</smiles>

13-QMa<smiles>C=C1C=C(C)C=C(C[N])C1=O</smiles>

13-QMb

Figure 6. Structure of bifunctional QM precursor 13 and the corresponding QMs.

of QMs to alkylate and cross-link DNA was assayed by investigation of the effects of QMs to DNA denaturing and the treatment of a plasmid DNA with compounds $\mathbf{2 a} \mathbf{a}-\mathbf{2 e}$ and $\mathbf{7}$, and KF, followed by the analysis by alkaline denaturing gel electrophoresis. Both methods did not provide evidence for the DNA cross-linking, in agreement with the MTT test performed on two human cancer cell lines (MCF7 breast adenocarcinoma and SUM159 pleomorphic breast carcinoma), which indicated that $\mathbf{2 a}-\mathbf{2 e}$ or the corresponding QMs did not exhibit significant cytotoxic activity. The lack of DNA reactivity was rationalized by sequential formation of QMs where bifunctional cytotoxic reagent is probably never produced. Instead, the sequential generation of monofunctional QM followed by a faster hydrolysis leads to the destruction of biologically active reagent. The findings described here are particularly important for the rational design of new generation of QM precursor molecules that should have structures that enable long-lived QM species such as 2,6-bifunctional phenols.

\section{EXPERIMENTAL}

\section{General}

Chemicals for the synthesis were purchased from the usual suppliers, whereas solvents for the synthesis and chromatographic separations were purified by distillation, or used as received (p.a. grade). ${ }^{1} \mathrm{H}$ and ${ }^{13} \mathrm{C} N M R$ spectra were recorded on a Bruker AV-300, 400 or 600 $\mathrm{MHz}$. The NMR spectra were taken in $\mathrm{CDCl}_{3}$ or DMSO- $d_{6}$ at rt using TMS as a reference. HRMS were obtained on an Applied Biosystems 4800 Plus MALDI TOF/TOF instrument ( $A B$, Foster City, $C A)$. For the sample analysis a Shimadzu HPLC equipped with a Diode-Array detector and a Phenomenex Luna $3 \mathrm{u} \mathrm{C18(2)} \mathrm{column} \mathrm{was} \mathrm{used.} \mathrm{Mobile}$ phase was $\mathrm{CH}_{3} \mathrm{OH}-\mathrm{H}_{2} \mathrm{O}$ (20 \%). For the chromatographic separations silica gel (Merck $0.05-0.2 \mathrm{~mm}$ ) was used. Analytical thin layer chromatography was performed on Polygram $^{\circledR}$ SILG/UV ${ }_{254}$ (Machery-Nagel) plates. In the irradiation experiments, $\mathrm{CH}_{3} \mathrm{CN}$ and $\mathrm{MeOH}$ were $\mathrm{HPLC}$ grade pure, and $\mathrm{mQ}-\mathrm{H}_{2} \mathrm{O}$ (Millipore) was used. ct-DNA was purchased from Aldrich. Preparation of known precursor molecule $\mathbf{5}$ is fully described in the ESI.
1-[2-(tert-Butyldimethylsilyloxy)phenyl]propane-1-ol (6) In a two neck flask ( $25 \mathrm{~mL}$ ), equipped with a condenser and septum, under inert $\mathrm{N}_{2}$ atmosphere, $\mathrm{Mg}(0.12 \mathrm{~g}, 4.94$ $\mathrm{mmol})$, dry THF ( $2 \mathrm{~mL}$ ) and a crystal of iodine were added. A small quantity of the solution of bromoethane $(0.36 \mathrm{~mL}$, $4.83 \mathrm{mmol}$ ) in THF ( $5 \mathrm{~mL}$ ) was added dropwise through the septum via a syringe. When the reaction was initiated by heating, the remaining bromoethane solution was added at rt. After the addition was complete, the reaction mixture was heated at the temperature of reflux $1 \mathrm{~h}$, cooled to rt, and a solution of the protected salicylaldehyde $(3,0.95 \mathrm{~g}$, $4.01 \mathrm{mmol})$ in THF ( $5 \mathrm{~mL}$ ) was added dropwise. The reaction mixture was stirred at $\mathrm{rt} 2 \mathrm{~h}$, and then a saturated aqueous solution of $\mathrm{NH}_{4} \mathrm{Cl}(5 \mathrm{~mL}$ ) was added, and the mixture was stirred $15 \mathrm{~min}$. The mixture was transferred to a separatory funnel, the layers were separated and the aqueous layer was extracted with ethyl acetate $(3 \times 15 \mathrm{~mL})$. The organic extracts were dried over anhydrous $\mathrm{MgSO}_{4}$, filtered, and the solvent was removed on a rotary evaporator. The residue was chromatographed on a column of silica gel using hexane/ethyl acetate $(7: 3)$ as eluent to afford the pure product $(0.89 \mathrm{~g}, 84 \%)$ in the form of colorless viscous oil.

${ }^{1} \mathrm{H}$ NMR $\left(\mathrm{CDCl}_{3}, 300 \mathrm{MHz}\right) \delta / \mathrm{ppm}: 7.36(\mathrm{dd}, 1 \mathrm{H}, J=$ $7.6 \mathrm{~Hz}, J=1.7 \mathrm{~Hz}), 7.13(\mathrm{td}, 1 \mathrm{H}, J=7.7 \mathrm{~Hz}, J=1.9 \mathrm{~Hz}), 6.95$ $(\mathrm{td}, 1 \mathrm{H}, J=7.4 \mathrm{~Hz}, J=0.8 \mathrm{~Hz}), 6.79(\mathrm{dd}, 1 \mathrm{H}, J=8.1 \mathrm{~Hz}, J=0.9$ $\mathrm{Hz}), 4.95-4.85(\mathrm{~m}, 1 \mathrm{H}), 2.12(\mathrm{~d}, 1 \mathrm{H}, J=4.5 \mathrm{~Hz}), 1.84-1.68(\mathrm{~m}$, 2H), $1.02(\mathrm{~s}, 9 \mathrm{H}), 0.3(\mathrm{~s}, 6 \mathrm{H}) .{ }^{13} \mathrm{C} \mathrm{NMR}\left(\mathrm{CDCl}_{3}, 100 \mathrm{MHz}\right)$ $\delta /$ ppm: 152.5, 134.8, 127.8, 126.8, 121.1, 118.1, 71.0, 30.4, $25.8,18.2,10.3,-4.02,-4.1$.

\section{1-[2-(tert-Butyldimethylsilyloxy)phenyl]prop-1-yl-acetate}

A two neck flask ( $5 \mathrm{~mL})$, equipped with a condenser and septum, under $\mathrm{N}_{2}$ inert atmosphere, was charged with 6 $(0.14 \mathrm{~g}, 0.52 \mathrm{mmol})$, ether $(2 \mathrm{~mL})$ and pyridine $(0.10 \mathrm{~mL}$, $1.24 \mathrm{mmol})$. The reaction mixture was heated at reflux for $5 \mathrm{~min}$ and then cooled to rt. Acetyl chloride $(0.09 \mathrm{~mL}, 1.27$ $\mathrm{mmol}$ ) was added and the mixture was heated at reflux for $3 \mathrm{~h}$. The solvent was removed on a rotary evaporator and the residue was chromatographed on a column of silica gel using hexane/diethyl ether (9:1) as eluent to afford the pure product $(0.055 \mathrm{~g}, 35 \%)$ in the form of colorless viscous oil. 
${ }^{1} \mathrm{H} \mathrm{NMR}\left(\mathrm{CDCl}_{3}, 600 \mathrm{MHz}\right) \delta / \mathrm{ppm}: 7.28(\mathrm{dd}, 1 \mathrm{H}, J=7.6$ $\mathrm{Hz}, J=1.6 \mathrm{~Hz}), 7.13(\mathrm{td}, 1 \mathrm{H}, J=8.0 \mathrm{~Hz}, J=1.5 \mathrm{~Hz}), 6.93(\mathrm{td}, 1 \mathrm{H}$, $J=7.5 \mathrm{~Hz}, J=0.8 \mathrm{~Hz}), 6.79(\mathrm{dd}, 1 \mathrm{H}, J=8.1 \mathrm{~Hz}, J=0.9 \mathrm{~Hz}), 6.09$ $(\mathrm{t}, 1 \mathrm{H}, J=6.4 \mathrm{~Hz}), 2.08(\mathrm{~s}, 3 \mathrm{H}), 1.84-1.77(\mathrm{~m}, 2 \mathrm{H}), 1.03(\mathrm{~s}, 9 \mathrm{H})$, $0.89(\mathrm{t}, 3 \mathrm{H}, J=7.4 \mathrm{~Hz}), 0.27(\mathrm{~s}, 6 \mathrm{H}) ;{ }^{13} \mathrm{C} \mathrm{NMR}\left(\mathrm{CDCl}_{3}, 150 \mathrm{MHz}\right)$ $\delta /$ ppm: 170.1, 152.4, 131.6, 128.1, 126.6, 120.9, 118.2, 71.9, 28.5, 25.7, 21.1, 19.4, 9.7, -4.1. HRMS (MALDI TOF/TOF): calcd. for $\mathrm{C}_{17} \mathrm{H}_{28} \mathrm{O}_{3} \mathrm{Si}[\mathrm{M}+\mathrm{H}]^{+}$309.1886; found 309.1880.

\section{One-pot Synthesis of 7}

In a two neck flask ( $25 \mathrm{~mL}$ ), equipped with a condenser and septum, under inert $\mathrm{N}_{2}$ atmosphere, $\mathrm{Mg}(0.060 \mathrm{~g}, 2.47$ $\mathrm{mmol})$, dry THF $(2 \mathrm{~mL})$ and a crystal of iodine were added. A small quantity of the solution of bromoethane $(0.18 \mathrm{~mL}$, $2.41 \mathrm{mmol}$ ) in THF (5 mL) was added dropwise through the septum via a syringe. When the reaction was initiated by heating, the remaining bromoethane solution was added at rt. After the addition was complete, the reaction mixture was heated at the temperature of reflux for $1 \mathrm{~h}$, cooled to $\mathrm{rt}$, and a solution of the protected salicylaldehyde $(3,0.47$ $\mathrm{g}, 2.00 \mathrm{mmol}$,) in THF ( $3 \mathrm{~mL}$ ) was added dropwise. The reaction mixture was stirred at $\mathrm{rt}$ for $1 \mathrm{~h}$, and then acetyl chloride $(0.18 \mathrm{~mL}, 2.53 \mathrm{mmol})$ was added and the stirring was continued over $2 \mathrm{~h}$. The solvent was removed on a rotary evaporator and the residue was purified on a column of silica gel using hexane/diethyl ether (9:1) as eluent to afford the pure product $(0.36 \mathrm{~g}, 58 \%)$ in the form of colorless viscous oil.

\section{Preparation of Bisphenol Derivatives 4 - General Procedure}

In a two neck flask (50 $\mathrm{mL}$ ), equipped with a condenser and septum, under inert $\mathrm{N}_{2}$ atmosphere, $\mathrm{Mg}(1.5 \mathrm{mmol})$, dry diethyl ether ( $1 \mathrm{~mL} / 1 \mathrm{mmol} \mathrm{Mg}$ ) and a crystal of iodine were added. A small quantity of the solution of $1, n$ dibromoalkane $(0.6 \mathrm{mmol})$ in ether $(5 \mathrm{~mL} / 1 \mathrm{mmol})$ was added dropwise through the septum via a syringe. When the reaction was initiated by heating, the remaining dibromoalkane solution was added at rt or with a moderate heating. After the addition was complete, the reaction mixture was heated at the temperature of reflux for $1 \mathrm{~h}$, cooled to rt, and a solution of the protected salicylaldehyde $(3,1 \mathrm{mmol})$ in dry ether $(2.5 \mathrm{~mL})$ was added dropwise. The reaction mixture was stirred at $\mathrm{rt}$ for $2 \mathrm{~h}$, and then a saturated aqueous solution of $\mathrm{NH}_{4} \mathrm{Cl}(5 \mathrm{~mL})$ was added and the mixture was stirred for $15 \mathrm{~min}$. The mixture was transferred to a separatory funnel, the layers were separated and the aqueous layer was extracted with ethyl acetate $(3 \times 15 \mathrm{~mL})$. The organic extracts were dried over anhydrous $\mathrm{MgSO}_{4}$, fil-tered, and the solvent was removed on a rotary evaporator. The residue was chromatographed on a column of silica gel using hexane/ethyl acetate (7:3) as eluent.

\section{1,6-Bis[2-(tert-butyldimethylsilyloxy)phenyl]hexane-1,6- diol (4a)}

According to the general procedure, the Grignard reagent was prepared from 1,4-dibromobutane $(0.395 \mathrm{~mL}, 3.30$ $\mathrm{mmol}$ ) and $\mathrm{Mg}(0.218 \mathrm{~g}, 8.97 \mathrm{mmol})$ in dry ether. In the reaction with the protected aldehyde $(5,1.30 \mathrm{~g}, 5.52 \mathrm{mmol})$ the product $(0.26 \mathrm{~g}, 48 \%)$ was obtained in the form of colorless viscous oil.

${ }^{1} \mathrm{H} \mathrm{NMR}\left(\mathrm{CDCl}_{3}, 300 \mathrm{MHz}\right) \delta / \mathrm{ppm}: 7.33(\mathrm{dd}, 2 \mathrm{H}, J=$ $7.6 \mathrm{~Hz}, J=1.4 \mathrm{~Hz}), 7.12(\mathrm{td}, 2 \mathrm{H}, J=8.0 \mathrm{~Hz}, J=1.7 \mathrm{~Hz}), 6.95$ $(\mathrm{td}, 2 \mathrm{H}, J=7.5 \mathrm{~Hz}, J=0.8 \mathrm{~Hz}), 6.78(\mathrm{dd}, 2 \mathrm{H}, J=8.0 \mathrm{~Hz}, J=0.7$ $\mathrm{Hz})$, 4.99-4.89 (m, 2H), 2.15 (br s, $2 \mathrm{H}), 1.80-1.69(\mathrm{~m}, 4 \mathrm{H})$, $1.45-1.31(\mathrm{~m}, 4 \mathrm{H}), 1.00(\mathrm{~s}, 18 \mathrm{H}), 0.26(\mathrm{~s}, 12 \mathrm{H}) ;{ }^{13} \mathrm{C} \mathrm{NMR}$ $\left(\mathrm{CDCl}_{3}, 75 \mathrm{MHz}\right) \delta / \mathrm{ppm}: 152.4,134.9,127.9,126.79$, 126.78, 121.2, 118.1, 69.86, 69.81, 37.5, 37.4, 26.2, 26.1, 25.8, 18.2, -4.1; HRMS (MALDI TOF/TOF): calcd for $\mathrm{C}_{30} \mathrm{H}_{50} \mathrm{O}_{4} \mathrm{Si}_{2}[\mathrm{M}+\mathrm{Na}]^{+}$553.3145; found 553.3140 .

\section{1,7-Bis[2-(tert-butyldimethylsilyloxy)phenyl]heptane-1,7- diol (4b)}

According to the general procedure, the Grignard reagent was prepared from 1,5-dibromopentane $(0.45 \mathrm{~mL}, 3.33 \mathrm{mmol})$ and $\mathrm{Mg}(0.22 \mathrm{~g}, 8.97 \mathrm{mmol})$ in dry ether. In the reaction with the protected aldehyde $(5,1.30 \mathrm{~g}, 5.52 \mathrm{mmol})$ the product $(0.26 \mathrm{~g}, 48 \%)$ was obtained in the form of colorless viscous oil.

${ }^{1} \mathrm{H} \mathrm{NMR}\left(\mathrm{CDCl}_{3}, 300 \mathrm{MHz}\right) \delta / \mathrm{ppm}: 7.34(\mathrm{dd}, 2 \mathrm{H}, \mathrm{J}=$ $7.5 \mathrm{~Hz}, J=1.5 \mathrm{~Hz}), 7.11(\mathrm{td}, 2 \mathrm{H}, J=7.8 \mathrm{~Hz}, J=1.7 \mathrm{~Hz}), 6.94$ $(\mathrm{dd}(\mathrm{t}), 2 \mathrm{H}, J=7.5 \mathrm{~Hz}), 6.78(\mathrm{~d}, 2 \mathrm{H}, J=7.8 \mathrm{~Hz}), 4.98-4.90(\mathrm{~m}$, $2 \mathrm{H}), 2.13-2.11(\mathrm{~m}, 2 \mathrm{H}), 1.76-1.69(\mathrm{~m}, 4 \mathrm{H}), 1.53-1.48(\mathrm{~m}$, $2 \mathrm{H}), 1.39-1.29(\mathrm{~m}, 4 \mathrm{H}), 1.01(\mathrm{~s}, 18 \mathrm{H}), 0.26(\mathrm{~s}, 12 \mathrm{H}) ;{ }^{13} \mathrm{C} \mathrm{NMR}$ $\left(\mathrm{CDCl}_{3}, 150 \mathrm{MHz}\right) \delta / \mathrm{ppm}: 152.4,134.9,127.8,126.7,121.1$, $118.1,69.7,37.4,29.7,26.0,25.7,18.1,-4.1$; HRMS (MALDI TOF/TOF): calcd. for $\mathrm{C}_{31} \mathrm{H}_{55} \mathrm{O}_{4} \mathrm{Si}_{2}[\mathrm{M}+\mathrm{Na}]^{+} 567.3302$; found 567.3309.

\section{1,8-Bis[2-(tert-butyldimethylsilyloxy)phenyl]octane-1,8- diol (4c)}

According to the general procedure, the Grignard reagent was prepared from 1,6-dibromohexane $(0.52 \mathrm{~mL}, 2.74$ $\mathrm{mmol})$ and $\mathrm{Mg}(0.22 \mathrm{~g}, 8.97 \mathrm{mmol})$ in dry ether. In the reaction with the protected aldehyde $(5,1.30 \mathrm{~g}, 5.52 \mathrm{mmol})$ the product $(0.26 \mathrm{~g}, 48 \%)$ was obtained in the form of colorless viscous oil.

${ }^{1} \mathrm{H}$ NMR $\left(\mathrm{CDCl}_{3}, 300 \mathrm{MHz}\right) \delta / \mathrm{ppm}: 7.34(\mathrm{dd}, 2 \mathrm{H}, \mathrm{J}=$ $7.5 \mathrm{~Hz}, J=1.6 \mathrm{~Hz}), 7.12(\mathrm{td}, 2 \mathrm{H}, J=8.0 \mathrm{~Hz}, J=1.8 \mathrm{~Hz}), 6.95$ $(\mathrm{td}, 2 \mathrm{H}, J=7.5 \mathrm{~Hz}, J=0.8 \mathrm{~Hz}), 6.78(\mathrm{dd}, 2 \mathrm{H}, J=8.0 \mathrm{~Hz}, J=0.8$ $\mathrm{Hz}), 4.98-4.90(\mathrm{~m}, 2 \mathrm{H}), 2.11(\mathrm{~d}, 2 \mathrm{H}, J=4.8 \mathrm{~Hz}), 1.76-1.69$ $(\mathrm{m}, 4 \mathrm{H}), 1.57-1.47(\mathrm{~m}, 2 \mathrm{H}), 1.36-1.26(\mathrm{~m}, 6 \mathrm{H}), 1.01(\mathrm{~s}, 18 \mathrm{H})$, $0.26(\mathrm{~s}, 12 \mathrm{H}) ;{ }^{13} \mathrm{C}$ NMR $\left(\mathrm{CDCl}_{3}, 150 \mathrm{MHz}\right) \delta / \mathrm{ppm}: 152.4$, 135.0, 127.8, 126.7, 121.1, 118.1, 69.7, 37.5, 29.6, 25.9, 25.7, 18.2, -4.1; HRMS (MALDI TOF/TOF): calcd for $\mathrm{C}_{32} \mathrm{H}_{54} \mathrm{O}_{4} \mathrm{Si}_{2}[\mathrm{M}+\mathrm{Na}]^{+}$581.3458; found 581.3469. 


\section{Acetylation of 4 - General Procedure}

A two neck flask (20 mL), equipped with a condenser and septum, under $\mathrm{N}_{2}$ inert atmosphere, was charged with $\mathbf{4}$ (1 $\mathrm{mmol})$, ether $(10 \mathrm{~mL})$ and pyridine $(4.4 \mathrm{mmol})$. The reaction mixture was heated at reflux for $5 \mathrm{~min}$ and then cooled to rt. Acetyl chloride $(4.5 \mathrm{mmol})$ was added and the mixture was heated at reflux for $30 \mathrm{~min}$. The solvent was removed on a rotary evaporator and the residue was chromatographed on a column of silica gel using hexane/diethyl ether (9:1) as eluent to afford the pure product.

\section{1,6-Bis[2-(tert-butyldimethylsilyloxy)phenyl]hexane-1,6- diacetate (2a)}

According to the general procedure, from $4 \mathrm{a}(0.27 \mathrm{~g}, 0.50$ $\mathrm{mmol})$, acetyl chloride $(0.16 \mathrm{~g}, 2.25 \mathrm{mmol})$ and pyridine the reaction furnished the product $(0.27 \mathrm{~g}, 87 \%)$ in the form of colorless viscous oil.

${ }^{1} \mathrm{H}$ NMR $\left(\mathrm{CDCl}_{3}, 300 \mathrm{MHz}\right) \delta / \mathrm{ppm}: 7.24(\mathrm{dd}, 2 \mathrm{H}, J=$ $7.3 \mathrm{~Hz}, J=1.5 \mathrm{~Hz}), 7.11(\mathrm{td}, 2 \mathrm{H}, J=7.5 \mathrm{~Hz}, J=1.6 \mathrm{~Hz}), 6.91$ $(\mathrm{td}, 2 \mathrm{H}, J=6.8 \mathrm{~Hz}, J=0.8 \mathrm{~Hz}), 6.76(\mathrm{dd}, 2 \mathrm{H}, J=8.1 \mathrm{~Hz}, J=0.6$ $\mathrm{Hz}), 6.09(\mathrm{t}, 2 \mathrm{H}, J=6.7 \mathrm{~Hz}), 2.04(\mathrm{~s}, 6 \mathrm{H}), 1.80-1.69(\mathrm{~m}, 4 \mathrm{H})$, 1.42-1.18 (m, 4H), $1.01(\mathrm{~s}, 18 \mathrm{H}), 0.25(\mathrm{~s}, 12 \mathrm{H}) ;{ }^{13} \mathrm{C}$ NMR $\left(\mathrm{CDCl}_{3}, 75 \mathrm{MHz}\right) \delta / \mathrm{ppm}: 169.9,152.3,131.7,128.1,126.5$, 120.9, 118.3, 70.9, 35.5, 25.7, 25.5, 21.1, 18.1, -4.1; HRMS (MALDI TOF/TOF): calcd. for $\mathrm{C}_{34} \mathrm{H}_{54} \mathrm{O}_{6} \mathrm{Si}_{2}[\mathrm{M}]^{+} 614.3459$; found 614.3429 .

\section{1,7-Bis[2-(tert-butyldimethylsilyloxy)phenyl]heptane-1,7- diacetate (2b)}

According to the general procedure, from $\mathbf{4 b}(0.27 \mathrm{~g}, 0.50$ $\mathrm{mmol})$, acetyl chloride $(0.16 \mathrm{~g}, 2.25 \mathrm{mmol})$ and pyridine the reaction furnished the product $(0.16 \mathrm{~g}, 50 \%)$ in the form of colorless viscous oil.

${ }^{1} \mathrm{H}$ NMR $\left(\mathrm{CDCl}_{3}, 300 \mathrm{MHz}\right) \delta / \mathrm{ppm}: 7.26$ (dd, $2 \mathrm{H}, J=$ $7.3 \mathrm{~Hz}, J=1.4 \mathrm{~Hz}), 7.11(\mathrm{td}, 2 \mathrm{H}, J=7.9 \mathrm{~Hz}, J=1.4 \mathrm{~Hz}), 6.92$ $(\mathrm{t}, 2 \mathrm{H}, J=7.3 \mathrm{~Hz}), 6.77(\mathrm{~d}, 2 \mathrm{H}, J=8.1 \mathrm{~Hz}), 6.09(\mathrm{t}, 2 \mathrm{H}, J=$ $6.5 \mathrm{~Hz}), 2.05(\mathrm{~s}, 6 \mathrm{H}), 1.80-1.68(\mathrm{~m}, 4 \mathrm{H}), 1.37-1.16(\mathrm{~m}, 6 \mathrm{H})$ $1.02(\mathrm{~s}, 18 \mathrm{H}), 0.26(\mathrm{~s}, 12 \mathrm{H}) ;{ }^{13} \mathrm{C} \mathrm{NMR}\left(\mathrm{CDCl}_{3}, 75 \mathrm{MHz}\right) \delta /$ ppm: 170.0, 152.3, 131.8, 128.0, 126.5, 120.9, 118.3, 70.9, 35.5, 29.4, 25.7, 25.4, 21.1, 18.1, -4.3; HRMS (MALDI TOF/TOF): calcd. for $\mathrm{C}_{35} \mathrm{H}_{56} \mathrm{O}_{6} \mathrm{Si}_{2}[\mathrm{M}]^{+}$628.3615; found 628.3606

\section{1,8-Bis[2-(tert-butyldimethylsilyloxy)phenyl]octane-1,8- diacetate (2c)}

According to the general procedure, from $4 \mathrm{c}(0.28 \mathrm{~g}, 0.50$ $\mathrm{mmol}$ ) and acetyl chloride $(0.16 \mathrm{~g}, 2.25 \mathrm{mmol})$ and pyridine the reaction furnished the product $(0.21 \mathrm{~g}, 65 \%)$ in the form of colorless viscous oil.

${ }^{1} \mathrm{H} \mathrm{NMR}\left(\mathrm{CDCl}_{3}, 300 \mathrm{MHz}\right) \delta / \mathrm{ppm}: 7.26(\mathrm{dd}, 2 \mathrm{H}, J=$ $7.3 \mathrm{~Hz}, J=1.4 \mathrm{~Hz}), 7.11(\mathrm{td}, 2 \mathrm{H}, J=7.9 \mathrm{~Hz}, J=1.4 \mathrm{~Hz}), 6.92$ $(\mathrm{t}, 2 \mathrm{H}, J=7.4 \mathrm{~Hz}), 6.77(\mathrm{dd}, 2 \mathrm{H}, J=8.0 \mathrm{~Hz}, J=0.5 \mathrm{~Hz}), 6.10$ $(\mathrm{t}, 2 \mathrm{H}, J=6.4 \mathrm{~Hz}), 2.05(\mathrm{~s}, 6 \mathrm{H}), 1.82-1.68(\mathrm{~m}, 4 \mathrm{H}), 1.31-1.18$ $(\mathrm{m}, 8 \mathrm{H}), 1.02(\mathrm{~s}, 18 \mathrm{H}), 0.26(\mathrm{~s}, 12 \mathrm{H}) ;{ }^{13} \mathrm{C}$ NMR $\left(\mathrm{CDCl}_{3}, 150\right.$ $\mathrm{MHz}) \delta / \mathrm{ppm}: 170.1,152.3,131.8,128.0,126.5,120.9$, $118.2,70.9,35.6,29.4,25.7,25.4,21.1,18.1,-4.1$; HRMS (MALDI TOF/TOF): calcd. for $\mathrm{C}_{36} \mathrm{H}_{58} \mathrm{O}_{6} \mathrm{Si}_{2}$ [M-H] 641.3694, found 641.3690 .

\section{One-pot synthesis of $\mathbf{2}$ - general procedure}

In a two neck flask $(50 \mathrm{~mL})$, equipped with a condenser and septum, under inert $\mathrm{N}_{2}$ atmosphere, $\mathrm{Mg}(1.3 \mathrm{mmol})$, dry ether $(2 \mathrm{~mL})$ and a crystal of iodine were added. A small quantity of the solution of the 1,n-dibromoalkane $(0.5$ $\mathrm{mmol})$ in ether $(5 \mathrm{~mL}$ ) was added dropwise through the septum via a syringe. When the reaction was initiated by heating, the remaining dibromoalkane solution was added at rt. After the addition was complete, the reaction mixture was heated at the temperature of reflux for $1 \mathrm{~h}$, cooled to $\mathrm{rt}$, and a solution of the protected salicylaldehyde $(3,1$ $\mathrm{mmol})$ in ether $(3 \mathrm{~mL})$ was added dropwise. The reaction mixture was stirred at $\mathrm{rt}$ for $2 \mathrm{~h}$, and then acetyl chloride ( $2.2 \mathrm{mmol}$ ) was added and the stirring was continued over $2 \mathrm{~h}$. The solvent was removed on a rotary evaporator and the residue was purified on a column of silica gel using hexane/diethyl ether (9:1) as eluent to afford the pure product in the form of colorless viscous oil.

\section{1,8-Bis[2-(tert-butyldimethylsilyloxy)phenyl]octane-1,8- diacetate (2c)}

According to the general procedure, the Grignard reagent was prepared from 1,6-dibromohexane $(0.30 \mathrm{~mL}, 1.43$ $\mathrm{mmol})$ and $\mathrm{Mg}(0.11 \mathrm{~g}, 4.48 \mathrm{mmol})$ in dry ether. In the reaction with the protected aldehyde $(5,0.65 \mathrm{~g}, 2.76$ $\mathrm{mmol})$, and subsequently acetyl chloride $(0.46 \mathrm{~mL}, 6.47$ $\mathrm{mmol}$ ) the product $(0.43 \mathrm{~g}, 48 \%)$ was obtained in the form of colorless viscous oil.

\section{1,9-Bis[2-(tert-butyldimethylsilyloxy)phenyl]nonane-1,9- diacetate (2d)}

According to the general procedure, the Grignard reagent was prepared from 1,7-dibromoheptane $(0.08 \mathrm{~mL}, 0.47$ $\mathrm{mmol})$ and $\mathrm{Mg}(0.04 \mathrm{~g}, 1.65 \mathrm{mmol})$ in dry ether. In the reaction with the protected aldehyde $(5,0.22 \mathrm{~g}, 0.93$ $\mathrm{mmol})$, and subsequently acetyl chloride $(0.13 \mathrm{~mL}, 1.83$ $\mathrm{mmol}$ ) the product (60 $\mathrm{mg}, 22 \%$ ) was obtained in the form of colorless viscous oil.

${ }^{1} \mathrm{H}$ NMR $\left(\mathrm{CDCl}_{3}, 600 \mathrm{MHz}\right) \delta / \mathrm{ppm}: 7.26$ (dd, $2 \mathrm{H}, J=$ $7.7 \mathrm{~Hz}, J=1.5 \mathrm{~Hz}), 7.11(\mathrm{td}, 2 \mathrm{H}, J=7.6 \mathrm{~Hz}, J=1.6 \mathrm{~Hz}), 6.92$ $(\mathrm{t}, 2 \mathrm{H}, J=7.6 \mathrm{~Hz}), 6.78(\mathrm{~d}, 2 \mathrm{H}, J=8.1 \mathrm{~Hz}), 6.11(\mathrm{t}, 2 \mathrm{H}, J=6.2$ $\mathrm{Hz}), 2.06(\mathrm{~s}, 6 \mathrm{H}), 1.81-1.69(\mathrm{~m}, 4 \mathrm{H}), 1.37-1.28(\mathrm{~m}, 2 \mathrm{H}), 1.26$ $1.19(\mathrm{~m}, 8 \mathrm{H}), 1.02(\mathrm{~s}, 18 \mathrm{H}), 0.26(\mathrm{~s}, 12 \mathrm{H}) ;{ }^{13} \mathrm{C} \mathrm{NMR}\left(\mathrm{CDCl}_{3}\right.$, $150 \mathrm{MHz}$ ) $\delta$ / ppm: 170.0, 152.3, 131.9, 128.0, 126.6, 120.9, 118.3 71.0, 35.6, 29.4, 29.3, 25.7, 25.4, 21.1, 18.1, -4.1; HRMS (MALDI TOF/TOF): calcd. for $\mathrm{C}_{37} \mathrm{H}_{60} \mathrm{O}_{6} \mathrm{Si}_{2}$ [M] 656.3928 ; found 656.3950 


\section{1,10-Bis[2-(tert-butyldimethylsilyloxy)phenyl]decane- 1,10-diacetate (2e)}

According to the general procedure, the Grignard reagent was prepared from 1,8-dibromooctane $(0.09 \mathrm{~mL}, 0.48$ $\mathrm{mmol})$ and $\mathrm{Mg}(0.04 \mathrm{~g}, 1.72 \mathrm{mmol})$ in dry ether. In the reaction with the protected aldehyde $(5,0.22 \mathrm{~g}, 0.93$ $\mathrm{mmol})$, and subsequently acetyl chloride $(0.13 \mathrm{~mL}, 1.83$ $\mathrm{mmol}$ ) the product ( $33 \mathrm{mg}, 11 \%$ ) was obtained in the form of colorless viscous oil.

${ }^{1} \mathrm{H}$ NMR $\left(\mathrm{CDCl}_{3}, 600 \mathrm{MHz}\right) \delta / \mathrm{ppm}: 7.27(\mathrm{dd}, 2 \mathrm{H}, J=$ $7.7 \mathrm{~Hz}, J=1.6 \mathrm{~Hz}), 7.11(\mathrm{td}, 2 \mathrm{H}, J=7.6 \mathrm{~Hz}, J=1.6 \mathrm{~Hz}), 6.92$ $(\mathrm{td}, 2 \mathrm{H}, J=7.4 \mathrm{~Hz}, J=0.6 \mathrm{~Hz}), 6.78(\mathrm{dd}, 2 \mathrm{H}, J=8.1 \mathrm{~Hz}, J=0.8$ $\mathrm{Hz}), 6.11(\mathrm{t}, 2 \mathrm{H}, J=6.6 \mathrm{~Hz}), 2.06(\mathrm{~s}, 6 \mathrm{H}), 1.82-1.69(\mathrm{~m}, 4 \mathrm{H})$, $1.27-1.18(\mathrm{~m}, 10 \mathrm{H}), 1.03(\mathrm{~s}, 18 \mathrm{H}), 0.26(\mathrm{~s}, 12 \mathrm{H}) ;{ }^{13} \mathrm{C} \mathrm{NMR}$ $\left(\mathrm{CDCl}_{3}, 150 \mathrm{MHz}\right) \delta / \mathrm{ppm}: 170.0,152.3,131.9,128.0,126.6$, 120.9, 118.3, 71.0, 35.6, 29.3, 25.7, 25.4, 21.1, 18.2, -4.3; HRMS (MALDI TOF/TOF): calcd. for $\mathrm{C}_{38} \mathrm{H}_{62} \mathrm{O}_{6} \mathrm{Si}_{2}[\mathrm{M}+\mathrm{Na}-\mathrm{H}]^{-}$ 692.3904; found 692.3893.

\section{2-(1-Azido-1-propyl)phenol (8)}

A flask ( $5 \mathrm{~mL}$ ) was charged with 7 ( $30 \mathrm{mg}, 0.09 \mathrm{mmol}$ ), sodium azide $(19 \mathrm{mg}, 0.29 \mathrm{mmol})$, acetonitrile $(0.6 \mathrm{~mL})$ and $\mathrm{H}_{2} \mathrm{O}(0.3$ $\mathrm{mL}$ ). To the reaction mixture, a solution of $\mathrm{KF}(12 \mathrm{mg}, 0.21$ $\mathrm{mmol})$ in $\mathrm{H}_{2} \mathrm{O}(0.3 \mathrm{~mL})$ was added dropwise. The reaction mixture was stirred at $\mathrm{rt}$ for $12 \mathrm{~h}$, diluted with $\mathrm{H}_{2} \mathrm{O}(10 \mathrm{~mL})$, and extracted with ethyl acetate $(3 \times 10 \mathrm{~mL})$. The organic extracts were dried over anhydrous $\mathrm{MgSO}_{4}$, filtered, and the solvent was removed on a rotary evaporator. The residue was chromatographed on a column of silica gel by use of $\mathrm{CH}_{2} \mathrm{Cl}_{2} / \mathrm{CH}_{3} \mathrm{OH}$ (9:1) as eluent to afford the pure product (8 $\mathrm{mg}, 47 \%$ ) in the form of colorless viscous oil.

${ }^{1} \mathrm{H} \mathrm{NMR}\left(\mathrm{CDCl}_{3}, 600 \mathrm{MHz}\right) \delta / \mathrm{ppm}: 7.19$ (td, $1 \mathrm{H}, J=8.0$ $\mathrm{Hz}, J=1.2 \mathrm{~Hz}$ ), $7.18(\mathrm{dd}, 1 \mathrm{H}, J=7.6 \mathrm{~Hz}, J=1.3 \mathrm{~Hz}), 6.91(\mathrm{td}, 1 \mathrm{H}$, $J=7.4 \mathrm{~Hz}, J=0.9 \mathrm{~Hz}), 6.85(\mathrm{dd}, 1 \mathrm{H}, J=8.0 \mathrm{~Hz}, J=0.9 \mathrm{~Hz}), 4.62$ (t, $1 \mathrm{H}, J=6.9 \mathrm{~Hz}), 1.94-1.81(\mathrm{~m}, 2 \mathrm{H}), 0.97(\mathrm{t}, 3 \mathrm{H}, J=7.3 \mathrm{~Hz}$ ).

\section{Methanolysis of $2 \mathrm{c}$}

Bisphenol 2c ( $30 \mathrm{mg}, 0.05 \mathrm{mmol}$ ) was dissolved in methanol $(2.0 \mathrm{~mL})$, and a solution of KF (19 mg, $0.33 \mathrm{mmol})$ in $\mathrm{H}_{2} \mathrm{O}$ $(0.3 \mathrm{~mL})$ was added dropwise. The mixture was stirred at $\mathrm{rt}$ for $1 \mathrm{~h}$, transferred to a separatory funnel, diluted with $\mathrm{H}_{2} \mathrm{O}$ $(10 \mathrm{~mL})$ and extracted with diethyl ether $(3 \times 5 \mathrm{~mL})$. The combined organic extracts were dried over anhydrous $\mathrm{MgSO}_{4}$, filtered and the solvent was removed on a rotary evaporator. The residue was purified on a column of silica gel using cyclohexane/EtOAc (7:1) as eluent to afford bisphenol 9 ( $8 \mathrm{mg}, 49 \%$ ) and 10 (6 mg, $33 \%$ ) in the form of colorless viscous oils.

2,2'-(1,8-Dimethoxyoctane-1,8-diyl)diphenol (9): ${ }^{1} \mathrm{H}$ NMR $\left(\mathrm{CDCl}_{3}, 600 \mathrm{MHz}\right) \delta / \mathrm{ppm}: 7.91(\mathrm{~s}, 2 \mathrm{H}), 7.20-7.16(\mathrm{~m}, 2 \mathrm{H})$, 6.93-6.90 (m, 2H), 6.87-6.85 (m, 2H), 6.84-6.81 (m, 2H), $4.22(\mathrm{t}, 2 \mathrm{H}, J=6.9 \mathrm{~Hz}), 3.37(\mathrm{~s}, 6 \mathrm{H}), 1.92-1.84(\mathrm{~m}, 2 \mathrm{H}), 1.72$ $1.63(\mathrm{~m}, 2 \mathrm{H}), 1.43-1.35(\mathrm{~m}, 2 \mathrm{H}), 1.31-1.19(\mathrm{~m}, 6 \mathrm{H}) ;{ }^{13} \mathrm{C}$ NMR $\left(\mathrm{CDCl}_{3}, 150 \mathrm{MHz}\right) \delta / \mathrm{ppm}: 155.3(\mathrm{~s}, 2 \mathrm{C}), 128.9$ (d, 2C), 128.4 (d, 2C), $125.0(\mathrm{~s}, 2 \mathrm{C}), 119.5$ (d, 2C), 116.7 (d, 2C), 86.0 (d, 2C), $57.2(\mathrm{q}, 2 \mathrm{C}), 35.8(\mathrm{t}, 2 \mathrm{C}), 29.2(\mathrm{t}, 2 \mathrm{C}), 25.6(\mathrm{t}, 2 \mathrm{C})$; HRMS (MALDI TOF/TOF): calcd. for $\mathrm{C}_{22} \mathrm{H}_{30} \mathrm{O}_{4}[\mathrm{M}+\mathrm{H}]^{+} 359.2222$; found 359.2235 .

1,8-Bis(2-hydroxyphenyl)-8-methoxyoctyl acetate (10): ${ }^{1} \mathrm{H}$ NMR $\left(\mathrm{CDCl}_{3}, 600 \mathrm{MHz}\right) \delta /$ ppm: $7.91(\mathrm{~d}, 1 \mathrm{H}, J=1.4 \mathrm{~Hz}), 7.30$ (br. $\mathrm{s}, 1 \mathrm{H}), 7.27-7.25(\mathrm{~m}, 1 \mathrm{H}), 7.23-7.19(\mathrm{~m}, 1 \mathrm{H}), 7.19-7.15(\mathrm{~m}, 1 \mathrm{H})$, $6.94-6.90(\mathrm{~m}, 3 \mathrm{H}), 6.86(\mathrm{dd}, 1 \mathrm{H}, J=8.1 \mathrm{~Hz}, J=1.0 \mathrm{~Hz}), 6.82(\mathrm{tt}$, $1 \mathrm{H}, J=6.3 \mathrm{~Hz}, J=1.0 \mathrm{~Hz}), 5.80(\mathrm{t}, 1 \mathrm{H}, J=7.0 \mathrm{~Hz}), 4.22(\mathrm{dd}(\mathrm{t})$, $1 \mathrm{H}, J=6.9 \mathrm{~Hz}$ ), $3.37(\mathrm{~d}, 3 \mathrm{H}, J=0.8 \mathrm{~Hz}), 2.07(\mathrm{~d}, 3 \mathrm{H}, J=1.2 \mathrm{~Hz}$ ), 2.07-2.01 (m, 1H), 1.91-1.81 (m, 2H), 1.72-1.65 (m, 1H), 1.34$1.16(\mathrm{~m}, 8 \mathrm{H}) ;{ }^{13} \mathrm{C} \mathrm{NMR}\left(\mathrm{CDCl}_{3}, 150 \mathrm{MHz}\right) \delta / \mathrm{ppm}: 172.6(\mathrm{~s})$, 155.3 (s), 154.6 (s), 129.9 (d), 128.9 (d), 128.4 (d), 127.4 (d), $125.6(\mathrm{~s}), 125.0$ (s), 120.8 (d), 119.6 (d), 118.0 (d), 116.7 (d), $86.0(d), 72.1(d), 57.2(q), 35.8(t), 33.5(t), 29.1(t), 29.0(t)$, $25.8(\mathrm{t}), 25.6(\mathrm{t}), 21.1(\mathrm{q})$; HRMS (MALDI TOF/TOF): calcd. for $\mathrm{C}_{23} \mathrm{H}_{30} \mathrm{O}_{5}[\mathrm{M}+\mathrm{H}]^{+}$387.2171; found 387.2160.

\section{Alkaline Agarose Gel Assay}

Plasmid CMVbeta DNA $(2 \mu \mathrm{g})$ was mixed with bisphenols 2a-2e $(1 \mathrm{mM})$ and $\mathrm{KF}(200 \mathrm{mM})$ in PBS buffer $(\mathrm{pH}=7.4)$. After $18 \mathrm{~h}$ incubation, the samples were added to the alkaline agarose gel loading buffer [50 mM NaOH, $1 \mathrm{mM}$ ethylenediaminetetraacetic acid (EDTA), $3 \%$ Ficoll, and $0.02 \%$ bromophenol blue] and loaded on a $1 \%$ agarose gel. Prior to the loading, the gel was soaked in $50 \mathrm{mM} \mathrm{NaOH}$ and $1 \mathrm{mM}$ EDTA for $1 \mathrm{~h}$, and the same solution was used as the running buffer. Gels were run at $30 \mathrm{~V}$ constant voltage in horizontal electrophoresis system (BIO-RAD, USA) for 5 h. After the run, gels were neutralized with $0.5 \mathrm{M}$ Tris $(\mathrm{pH}$ 7) for $30 \mathrm{~min}$, and stained with ethidium bromide $(1 \mu \mathrm{g} / \mathrm{mL})$ for $30 \mathrm{~min}$. Resulting products were visualized and documented with UV light at $254 \mathrm{~nm}$ (Image Master VDS, Pharmacia Biotech, Sweden). As a positive control, instead of 2 and KF, the plasmid was treated with psoralene $(20$ $\mu \mathrm{M})$ and irradiated in a Luzchem reactor $5 \mathrm{~min}$ with 6 lamps (1 lamp $8 \mathrm{~W}$ ) at $300 \mathrm{~nm}$.

\section{DNA Denaturation Experiments}

For the DNA denaturation experiments, a stock solution of compound 2 was prepared in DMSO $\left(c=2 \times 10^{-2} \mathrm{M}\right)$, whereas a stock solution of ct-DNA $\left(c=1.1 \times 10^{-3} \mathrm{M}\right)$ and a stock solution of $\mathrm{KF}(c=0.2 \mathrm{M})$ were prepared in $\mathrm{H}_{2} \mathrm{O}-\mathrm{DMSO}$ (8:2), containing sodium cacodylate $(c=0.05 \mathrm{M}, \mathrm{pH}=7.0)$. The cross-linking was attempted by a treatment of DNA solution $(20 \mu \mathrm{L})$ with compound $2(10 \mu \mathrm{L})$ and $\mathrm{KF}(20 \mu \mathrm{L})$ which were incubated $3 \mathrm{~h}$. This solution $(40 \mu \mathrm{L})$ was then diluted [(ct-DNA $\left(c=1.76 \times 10^{-5} \mathrm{M}\right)$, in the presence of 2 $\left(c=1.6 \times 10^{-4} \mathrm{M}\right)$, and KF $\left.(0.2 \mathrm{M})\right]$ and the dependence of the absorbance at $260 \mathrm{~nm}$ as a function of temperature was 
measured. The melting temperature $T_{\mathrm{m}}$ values are the midpoints of the transition curves, determined from the maximum of the first derivative. $\Delta T_{\mathrm{m}}$ values were calculated by subtracting $T_{\mathrm{m}}$ of the free nucleic acid from that of the respective complex with $\Delta T_{\mathrm{m}}$ values are the average of at least two independent measurements and the error in $\Delta T_{\mathrm{m}}$ is ca. $\pm 0.5^{\circ} \mathrm{C}$.

\section{Antiproliferative Investigation}

MTT test was conducted on 2 human tumour cell lines, MCF7 (breast adenocarcinoma) and SUM159 (pleomorphic breast carcinoma). MCF7 cells were cultured as monolayers and maintained in DMEM medium, supplemented with 10 $\%$ fetal bovine serum (FBS), $2 \mathrm{mM}$ L-glutamine, $100 \mathrm{U} / \mathrm{mL}$ penicillin and $100 \mu \mathrm{g} / \mathrm{mL}$ streptomycin in a humidified atmosphere with $5 \% \mathrm{CO}_{2}$ at $37{ }^{\circ} \mathrm{C}$. The cell line SUM159 was maintained using the same conditions, but in different cell media: Ham's F12 medium supplemented with $5 \%$ fetal bovine serum, $2 \mathrm{mM} \mathrm{L-glutamine,} 100 \mathrm{U} / \mathrm{mL}$ penicillin and $100 \mu \mathrm{g} / \mathrm{mL}$ streptomycin, $5 \mu \mathrm{g} / \mathrm{mL}$ insulin, $1 \mu \mathrm{g} / \mathrm{mL}$ hydrocortisone. Cell lines were inoculated in parallel onto a series of standard 96-well microtiter plates on day 0 . The cells were seeded at $2 \times 10^{4}$ cells $/ \mathrm{mL}$ for SUM159 and $3 \times 10^{4}$ cells/mL for MCF7, depending on the doubling times of specific cell line. Test agents were then added in five 10fold dilutions $\left(10^{-8}\right.$ to $\left.10^{-4} \mathrm{M}\right)$ and incubated for a further $72 \mathrm{~h}$. For each cell line one of the plates was treated with $1 \mathrm{mM} \mathrm{KF}$, concentration that has low impact on cells (see supporting information) while the other was treated with the cell culture medium, $2 \mathrm{~h}$ after the addition of the compounds. Suitable concentration of KF was determined in advance by titration of KF using the same cell lines (see the Supporting material, Figure S3). Working dilutions of compounds were freshly prepared on the day of testing. After $72 \mathrm{~h}$ of incubation, the cell growth rate was evaluated by performing the MTT assay, as described previously. ${ }^{[22,23]}$ The results were expressed as $\mathrm{IC}_{50}$, a concentration necessary for $50 \%$ of inhibition. The $I C_{50}$ values for each compound were calculated from concentration-response curves using linear regression analysis. Each result is an average value from at least two separate experiments.

Acknowledgment. These materials are based on work financed by the Croatian Science Foundation (HRZZ grant no. HRZZ IP-2014-09-6312 to NB and IP-2013-5660 to MK). Authors acknowledge generous support from Fidelta Ltd.

Supplementary Information. Synthetic procedures for the preparation of known intermediates, Investigation of the DNA cross-linking by thermal denaturation, Antiproliferative activity and KF cytotoxicity data, ${ }^{1} \mathrm{H}$ and ${ }^{13} \mathrm{C}$ NMR spectra of all new compounds. Supporting information to the paper is attached to the electronic version of the article at: http://doi.org/10.5562/cca3455.
PDF files with attached documents are best viewed with Adobe Acrobat Reader which is free and can be downloaded from Adobe's web site.

\section{REFERENCES}

[1] S. E. Rokita (Ed.), Quinone Methides, Wiley, Hoboken USA, 2009. https://doi.org/10.1002/9780470452882

[2] (a) R. Van De Water, T. R. R. Pettus, Tetrahedron 2002, 58, 5367-5405.

(b) T. P. Pathak, M. S. Sigman, J. Org. Chem. 2011, 76, 9210-9215. https://doi.org/10.1021/jo201789k

(c) A. A. Jaworski, A. K. Scheidt, J. Org. Chem. 2016, 81, 10145-10153.

https://doi.org/10.1021/acs.joc.6b01367

(d) M. S. Singh, A. Nagaraju, N. Anand, S. Chowdhury, RSC Adv. 2014, 4, 55924-55959.

(e) W.-J. Bai, J. G. David, Z.-G. Feng, M. G. Weaver, K. Wu, T. R. R. Pettus, Acc. Chem. Res. 2014, 47, 36553664. https://doi.org/10.1021/ar500330x

[3] (a) M. Freccero, Mini Rev. Org. Chem. 2004, 1, 403415. https://doi.org/10.2174/1570193043403091

(b) P. Wang, Y. Song, L. Zhang, H. He, X. Zhou, Curr. Med. Chem. 2005, 12, 2893-2913.

https://doi.org/10.2174/092986705774454724

[4] E. Modica, R. Zanaletti, M. Freccero, M. Mella, J. Org. Chem. 2001, 66, 41-52.

https://doi.org/10.1021/jo0006627

[5] S. Arumugam, J. Guo, N. E. Mbua, F. Fiscourt, N. Lin, E. Nekongo, G. J. Boons, V. V. Popik, Chem. Sci. 2014, 5, 1591-1598. https://doi.org/10.1039/C3SC51691A

[6] I. A. McDonald, P. L. Nyce, M. J. Jung, J. S. Sabol, Tetrahedron Lett. 1991, 32, 887-890. https://doi.org/10.1016/S0040-4039(00)92112-9

[7] D. Cabaret, S. A. Adediran, M. J. G. Gonzalez, R. F. Pratt, M. Wakselman, J. Org. Chem. 1999, 64, 713720. https://doi.org/10.1021/jo980564+

[8] S.-K. Chung, J. W. Lee, N. Y. Shim, T. W. Kwon, Bioorg. Med. Chem. Lett. 1996, 6, 1309-1312. https://doi.org/10.1016/0960-894X(96)00218-1

[9] (a) Q. Wang, U. Dechert, F. Jirik, S. G. Withers, Biochem. Biophys. Res. Commun. 1994, 200, 577583. https://doi.org/10.1006/bbrc.1994.1487

(b) J. K. Myers, J. D. Cohen, T. S. Widlanski, J. Am. Chem. Soc. 1995, 117, 11049-11054. https://doi.org/10.1021/ja00150a002

[10] J. K. Storwell, T. S. Widlanski, T. G. Kutaleladze, R. T. Raines, J. Org. Chem. 1995, 60, 6930-6936. https://doi.org/10.1021/jo00126a051

[11] (a) S. E. Rokita, J. Yang, P. Pande, W. A. Greenberg, J. Org. Chem. 1997, 62, 3010-3012. https://doi.org/10.1021/jo9700336 (b) W. F. Veldhuyzen, A. J. Shallop, R. A. Jones, S. E. Rokita, J. Am. Chem. Soc. 2001, 123, 11126-11132. https://doi.org/10.1021/ja011686d 
(c) E. E. Weinert, K. N. Frankenfield, S. E. Rokita, Chem. Res. Toxicol. 2005, 18, 1364-1370. https://doi.org/10.1021/tx0501583

(d) P. Wang, R. Liu, X. Wu, H. Ma, X. Cao, P. Zhou, J. Zhang, X. Weng, X.-L. Zhang, J. Qi, X. Zhou, L. Weng, J. Am. Chem. Soc. 2003, 125, 1116-1117.

https://doi.org/10.1021/ja029040o

(e) E. E. Weinert, D. Ruggero, S. Colloredo-Melz, K. N. Frankenfield, C. H. Mitchell, M. Freccero, S. E. Rokita, J. Am. Chem. Soc. 2006, 128, 11940-11947. https://doi.org/10.1021/ja062948k

[12] (a) M. Chatterjee, S. E. Rokita, J. Am. Chem. Soc. 1994, 116, 1690-1697.

https://doi.org/10.1021/ja00084a009

(b) Q. Zeng, S. E. Rokita, J. Org. Chem. 1996, 61, 9080-9081. https://doi.org/10.1021/jo961864z

(c) P. Pande, J. Shearer, J. Yang, W. A. Greenberg, S. E. Rokita, J. Am. Chem. Soc. 1999, 121, 6773-6779. https://doi.org/10.1021/ja990456k

(d) D. Verga, M. Nadai, F. Doria, C. Percivalle, M. Di Antonio, M. Palumbo, S. N. Richter, M. Freccero, J. Am. Chem. Soc. 2010, 132, 14625-14637. https://doi.org/10.1021/ja1063857

[13] (a) V. S. Li, H. Kohn, J. Am. Chem. Soc. 1991, 113, 275-283. https://doi.org/10.1021/ja00001a040 (b) I. Han, D. J. Russell, H. Kohn, J. Org. Chem. 1992, 57, 1799-1807. https://doi.org/10.1021/jo00032a037

(c) M. Tomasz, A. Das, K. S. Tang, M. G. J. Ford, A. Minnock, S. M. Musser, M. J. Waring, J. Am. Chem. Soc. 1998, 120, 11581-11593.

https://doi.org/10.1021/ja9824019

[14] (a) H. Wang, M. S. Wahi, S. E. Rokita, Angew. Chem. Int. Ed. 2008, 47, 1291-1293.

https://doi.org/10.1002/anie.200704137

(b) H. Wang, S. E. Rokita, Angew. Chem. Int. Ed. 2010, 49, 5957-5960. https://doi.org/10.1002/anie.201001597

(c) C. S. Rossiter, E. Modica, D. Kumar, S. E. Rokita, Chem. Commun. 2011, 47, 1476-1478. https://doi.org/10.1039/C0CC03317K

[15] (a) M. Nadai, F. Doria, M. Di Antonio, G. Sattin, L. Germani, C. Percivalle, M. Palumbo, S. N. Richter, M. Freccero, Biochemie 2011, 93, 1328-1340.

https://doi.org/10.1016/j.biochi.2011.06.015

(b) F. Doria, M. Nadai, M. Folini, M. Di Antonio, L. Germani, C. Percivalle, C. Sissi, N. Zaffaroni, S. Alcaro, A. Artese, S. N. Richter, M. Freccero, Org. Biomol. Chem. 2012, 10, 2798-2806.

https://doi.org/10.1039/c2ob06816h

(c) F. Doria, M. Nadai, M. Folini, M. Scalabrin, L. Germani, G. Sattin, M. Mella, M. Palumbo, N. Zaffaroni, D. Fabris, M. Freccero, S. N. Richter, Chem. Eur. J. 2013, 19, 78-81.

https://doi.org/10.1002/chem.201203097
[16] D. A. Bolon, J. Org. Chem. 1970, 35, 3666-3670. https://doi.org/10.1021/jo00836a016

[17] (a) G. G.-H. Qiao, K. Lenghaus, D. H. Solomon, A. Reisinger, I. Bytheway, C. Wentrup, J. Org. Chem. 1998, 63, 9806-9811. https://doi.org/10.1021/jo981445x

(b) E. Dorrestijn, M. Kranenburg, M. V. Ciriano, P. Mulder, J. Org. Chem. 1999, 64, 3012-3018. https://doi.org/10.1021/jo981110f

[18] M. Yato, T. Ohwada, K. Shudo, J. Am. Chem. Soc. 1990, 112, 5341-5342. https://doi.org/10.1021/ja00169a046

[19] (a) N. Basarić, K. Mlinarić-Majerski, M. Kralj, Curr. Org. Chem. 2014, 18, 3-18.

https://doi.org/10.2174/138527281801140121122330

(b) C. Percivalle, F. Doria, M. Freccero, Curr. Org. Chem. 2014, 18, 19-43. https://doi.org/10.2174/13852728113176660135

[20] L. Diao, C. Yang, P. Wan, J. Am. Chem. Soc. 1995, 117, 5369-5370. https://doi.org/10.1021/ja00124a024

[21] (a) K. Nakatani, N. Higashida, I. Saito, Tetrahedron Lett. 1997, 38, 5005-5008.

https://doi.org/10.1016/S0040-4039(97)01071-X

(b) Đ. Škalamera, C. Bohne, S. Landgraf, N. Basarić, J. Org. Chem. 2015, 80, 10817-10828.

https://doi.org/10.1021/acs.joc.5b01991

[22] (a) N. Basarić, N. Cindro, D. Bobinac, K. MlinarićMajerski, L. Uzelac, M. Kralj, P. Wan, Photochem. Photobiol. Sci. 2011, 10, 1910-1925. https://doi.org/10.1039/c1pp05182b

(b) N. Basarić, N. Cindro, D. Bobinac, L. Uzelac, K. Mlinarić-Majerski, M. Kralj, P. Wan, Photochem. Photobiol. Sci. 2012, 11, 381-396.

https://doi.org/10.1039/c1pp05338h

(c) J. Veljković, L. Uzelac, K. Molčanov, K. MlinarićMajerski, M. Kralj, P. Wan, N. Basarić, J. Org. Chem. 2012, 77, 4596-4610.

https://doi.org/10.1021/jo3002479

(d) M. Kralj, L. Uzelac, Y.-H. Wang, P. Wan, M. Tireli, K. Mlinarić-Majerski, I. Pinatanida, N. Basarić, Photochem. Photobiol. Sci. 2015, 14, 1082-1092.

https://doi.org/10.1039/C5PP00099H

(e) Đ. Škalamera, K. Mlinarić-Majerski, I. Martin Kleiner, M. Kralj, J. Oake, P. Wan, C. Bohne, N. Basarić, J. Org. Chem. 2017, 82, 6006-6021. https://doi.org/10.1021/acs.joc.6b02735

[23] L. Uzelac, Đ. Škalamera, K. Mlinarić-Majerski, N. Basarić, M. Kralj, Eur. J. Med. Chem. 2017, 137, 558-574. https://doi.org/10.1016/j.ejmech.2017.05.063

[24] S. R. Rajski, R. M. Williams, Chem. Rev. 1998, 98, 2723-2796. https://doi.org/10.1021/cr9800199

[25] S. Kobayashi, T. Semba, T. Takahashi, S. Yoshida, K. Dai, T. Otani, T. Saito, Tetrahedron 2009, 65, 920933. https://doi.org/10.1016/j.tet.2008.10.090 
[26] K. Maruyama, T. Katagiri, J. Phys.Org. Chem. 1989, 2, 205-213. https://doi.org/10.1002/poc.610020303

[27] E. C. Ashby, Pure Appl. Chem. 1980, 52, 545-569. https://doi.org/10.1351/pac198052030545
[28] F. Bickelhaupt, Pure Appl. Chem. 1986, 58, 537-542. https://doi.org/10.1351/pac198658040537

[29] F. Fakhari, S. E. Rokita, Nature Commun. 2014, 5, 5591. https://doi.org/10.1038/ncomms6591 